\title{
Researches on Blood Biochemical Variations During Pregnancy in Rabbits
}

\author{
ROXANA LAZAR ${ }^{1}$, CATALIN RAZVAN VINTU2*, PAUL CORNELIU BOISTEANU1*, DANIEL SIMEANU ${ }^{1}$, RADU ANTOHE ${ }^{3}$ \\ IUniversity of Agricultural Sciences and Veterinary Medicine of lasi, 3 Mihail Sadoveanu Alley 700490, lasi, Romania \\ ¿University of Agricultural Sciences and Veterinary Medicine of Bucharest, 59 Marasti Av., 011464, Bucharest, Romania \\ ${ }^{3}$ Bucharest University of Economic Studies, 6 Romana Sq., 010374 Bucharest, Romania
}

\begin{abstract}
The organism as a biological system, for the normal performance of its functions, needs a wide variety of substances that it needs to obtain from the environment. Their assurance must be rhythmic and balanced in qualitative and quantitative terms. By its chemical composition, the blood plasma transports the energetic and plastic substances from the forming organs to the cells and tissues, but also the products resulting from the cellular and tissue catabolism of the excretory organs. The research was carried outon the Meuse Rabbit by the Belgian Giant, divided into three experimental NP groups (adult, non-pregnant females), P1 (females at 15 days of gestation) and P2 (females at the end of gestation, 30 days). The collection of blood samples was performed with the vacuum system before meals. Subsequently, they were centrifuged at $3000 \mathrm{rpm}$ for 5 minutes to obtain the plasma required for the biochemical examination. Biochemical parameters were determined by spectophotometry using the ACCENT 200. As a result, we observed that gestation is a diabetogenic stress, the fetus uses glucose almost exclusively as an energy source and increases protein needs due to the permanent transfer of amino acids to the fetus. Lipid metabolism is diverted with priority to lipid consumption, about $20 \%$ of free circulating fatty acids are transferred to the fetus.
\end{abstract}

Keywords: blood biochemistry, protein metabolism, lipid metabolism

For the normal performance of its functions, the organism as a biological system, needs a wide variety of substances (essential amino acids, carbohydrates, lipids, vitamins, minerals, water) which must acquire from the environment [1,2]. Their assurance must have a rhythmic and balanced character, both qualitatively and quantitative [3-5].

During pregnancy there are some important trophic changes caused by the nervous adjustment $[6,7]$. After implantation, the fertilized oocyte excites the nerve endings of mucosal tunics of the uterus, which generates the body reaction response [8]. The adrenal cortex influences the activity of central nervous system (CNS) and cellular metabolic changes, with the involvement of all types of metabolism within the female organism $[9,10]$. The biological center of changes is the fetus and as it develops, it enhances the nutritional necessity and elimination of metabolic products [11, 12].

The detection of nutritional and metabolic disorders should be done in early stages of pregnancy [13, 14]. For this, metabolic health tests are required, which allow both early recognition of nutritional deficiencies, as well as assessing the ability to adapt the organism $[15,16]$. Metabolic profile tests representan excellent tool for group prognosis, evaluating the specific and general defensive capacity of individuals within a population. It can also explain the surprisingly high morbidity similar to some infectious diseases and even with the failure of a specific preventive action [17].

In healthy clinical females, metabolic profile indices were identified in correlation with reproduction indices, knowing that by non-compliance with the requirements of food and maintenance, various dysmetabolites that are negatively reflected on conception products $[18,19]$.

\section{Experimental part}

Material and methods

The researches were carried out on Giant Belgian rabbit crossbreed, divided into three experimental groups NP (adult females, nonpregnant), P1 (females at 15 days of pregnancy) and P2 (females at the end of pregnancy - on day 30 of pregnancy). Each experimental group consisted of 14 specimens. The pregnant females were maintained in three breeding nests with which the battery was provided, with a width of $35 \mathrm{~cm}$, the hole of nest having a circular shape, with a threshold of $10 \div 15 \mathrm{~cm}$ high, necessary to maintain the bedding and to retain the rabbit kits when attached to the lactating doe nipples at the time of its exit from the nest. The feeding was carried out with granulated combined fodder, produced from a homogenized mixture of ground grain, soybean meal, sunflower meal, calcium carbonate, dicalcium phosphate, amino acids, alfalfa flour and vitamin-mineral premixes. Access to water has been uninterrupted.

The harvesting of blood samples was carried out with the vacuum system, on empty stomach. Subsequently, the samples were centrifuged at 3000 rotations for 5 minutes in order to obtain the plasma necessary for biochemical examination [20]. The biochemical parameters were determined using the ACCENT 200 analyzer [21, 22] .

\section{Results and discussions}

The concentration of total serum proteins achieve the constant called proteinemia, which depends on hormonal and hydric balance of body, on state of nutrition and on numerous factors that influence the health of body [11, 23].

In rabbits the concentration of total proteins may also occur following venous stasis during blood harvesting, as 
fluids and small molecules leave the blood plasma, or may indicate a state of dehydration, which in rabbits is encountered quite often [24-26].

Analyzing the results obtained, we observed that the lowest values of total proteins were recorded in day 15 of pregnancy [27]. This decrease may be associated with the growth and development of the fetus, in particular with the increasing demand of amino acids required for the synthesis of proteins in the fetal muscles [28].

Table 1

CHANGES IN SERUM PROTEIN LEVELS IN STUDIED DOES

\begin{tabular}{|c|c|c|c|}
\hline $\begin{array}{c}\text { Protein } \\
\text { (g/dL) }\end{array}$ & $\begin{array}{c}\text { Adult females } \\
\text { NP }\end{array}$ & $\begin{array}{c}\text { Females at } 15 \\
\text { days of gestation } \\
\text { Pl }\end{array}$ & $\begin{array}{c}\text { Females at } 15 \\
\text { days of gestation } \\
\text { P2 }\end{array}$ \\
\hline$\overline{\mathrm{x}} \pm s_{\mathrm{z}}$ & $5.85 \pm 0.36$ & $5.10 \pm 0.30$ & $5.35 \pm 0.25$ \\
\hline $\mathrm{V} \%$ & 16.70 & 15.79 & 12.62 \\
\hline ANOVA & \multicolumn{3}{|c|}{$\begin{array}{l}\text { M1 vs. } M 2=\text { n.s. }\left(\hat{\mathrm{F}}_{2,46}<\mathrm{F}_{0,05 \%}(4,75)\right) \\
\mathrm{M} 1 \text { vs. } \mathrm{M} 3=\text { n.s. }\left(\hat{\mathrm{F}}_{1,25}<\mathrm{F}_{0,05 \%}(4,75)\right) \\
\mathrm{M} 2 \text { vs. } \mathrm{M} 3=\text { n.s. }\left(\hat{\mathrm{F}}_{0,39}<\mathrm{F}_{0,05 \%}(4,75)\right)\end{array}$} \\
\hline
\end{tabular}

The values obtained, on the amount of total protein, in the three physiological phases taken under consideration were similar with the results obtained by Wahab. A. in 2016 [29].

Biochemical determinations on lipid metabolism have been performed. It is characterized by the transfer of fatty acids from mother to fetus, maternal consumption of fatty acids for energy purposes and depositing large amounts of fat reserves, especially in mother's subcutaneous tissue [30]. It is know $n$ and has been observed in our studies that the plasmatic concentration of free fatty acids increases with the development of pregnancy, due to increase of free fatty acids synthesis in the liver. The quantity of stored lipids represents an important energy reserve to ensure energy needs during pregnancy [31, 32].

Cholesterol at the body level is synthesized in the liver or can be obtained from food rations, being a steroid hormones precursor. It is metabolized in the liver and is subsequently excreted by the bile. Cholesterol values determined significant differences between the studied groups. Thus, the lowest values were obtained in the NP females, respectively $11.85 \mathrm{mg} / \mathrm{dL}$. Prior to pregnancy, females registered lower values compared to those at the end of pregnancy, $49.28 \mathrm{mg} / \mathrm{dL}$. The same variation could be observed between the females halfway through the breeding period and those in the last pregnancy period. The total cholesterol levels in the nonpregnant adult females and in the mid-pregnancy period were much lower than those obtained by Al Eissa in 2011 [27] (table 2).

Being storage lipids, triglycerides are used in physiological adjustments of energy metabolism [33, 34]. In the second half of pregnancy, due to the process of organogenesis it was necessary to mobilize increased amounts of energy, which explains the low value of triglycerides in the mid-pregnancy period - $23.88 \mathrm{mg} / \mathrm{dL}$ (table 3).

Blood glucose levels undergo changes during fetal development, it decreases once the pregnancy progresses due to increased absorption of glucose by the placenta and inhibition of gluconeogenesis [35]. Another cause for intensified ketogenesis is the action of placental hormones on maternal hepatocytes. The ketone bodies (acetoacetic acid, p-hydroxybutyric acid) diffuses the placenta and are assimilated by the fetus's liver and brain, as an energy source [36]. In the firsthalf of pregnancy due to preprandial hypoglycemia increases the sensitivity of maternal tissues to insulin. In the last period of pregnancy, the level of placental hormones that inhibit the use of glucose by maternal tissues increases considerably, ensuring access to adequate amount of glucose in the fetoplacental system [37]. In the current study, no significant differences were recorded between the three periods (table 4), a slight decrease in glucose value was observed towards the end of pregnancy. The results are similar with those obtained by Talvekar et al. in 2008 [38].

Biochemical determinations on enzymatic activity of liver also involved testing for aspartate aminotransferase

\begin{tabular}{|c|c|c|c|}
\hline $\begin{array}{l}\text { Cholesterol } \\
(\mathrm{mg} / \mathrm{dL})\end{array}$ & $\begin{array}{c}\text { Adult females } \\
\text { NP }\end{array}$ & $\begin{array}{c}\text { Females at } 15 \text { days of } \\
\text { gestation } \\
\text { Pl }\end{array}$ & $\begin{array}{c}\text { Females at } 15 \text { days of } \\
\text { gestation } \\
\text { P2 }\end{array}$ \\
\hline$\overline{\mathbf{x}} \pm s_{\mathrm{x}}$ & $11.85 \pm 2.80$ & $12.71 \pm 0.91$ & $49.28 \pm 9.20$ \\
\hline $\mathrm{V} \%$ & 62.62 & 19.11 & 49.41 \\
\hline ANOVA & \multicolumn{3}{|c|}{$\begin{array}{l}\text { M1 vs. } M 2=\text { n.s. }\left(\hat{\mathrm{F}}_{0,08}<\mathrm{F}_{0,05 \%}(4,75)\right) \\
\text { M1 vs. } \mathrm{M} 3=* *\left(\hat{\mathrm{F}}_{15,12}>\mathrm{F}_{0,01 \%}(9,33)\right) \\
\text { M2 vs. } \mathrm{M} 3=* *\left(\hat{\mathrm{F}}_{15,62}>\mathrm{F}_{0,01 \%}(9,33)\right)\end{array}$} \\
\hline
\end{tabular}

\begin{tabular}{|c|c|c|c|}
\hline $\begin{array}{l}\text { Triglycerides } \\
\text { (mg/dL) }\end{array}$ & $\begin{array}{c}\text { Adult females } \\
\text { NP }\end{array}$ & $\begin{array}{c}\text { Females at } 15 \text { days of } \\
\text { gestation } \\
\text { P1 }\end{array}$ & $\begin{array}{c}\text { Females at } 15 \text { days of } \\
\text { gestation } \\
\text { P2 }\end{array}$ \\
\hline$\overline{\mathrm{x}} \pm s_{\mathrm{x}}$ & $25.60 \pm 3.80$ & $23.88 \pm 1.51$ & $62.71 \pm 4.80$ \\
\hline $\mathrm{V} \%$ & 39.33 & 16.75 & 20.28 \\
\hline ANOVA & \multicolumn{3}{|c|}{$\begin{array}{c}\mathrm{M} 1 \text { vs. } \mathrm{M} 2=\text { n.s. }\left(\hat{\mathrm{F}}_{0,17}<\mathrm{F}_{0,05 \%}(4,75)\right) \\
\mathrm{M} 1 \text { vs. } \mathrm{M} 3=* * *\left(\hat{\mathrm{F}}_{36,60}>\mathrm{F}_{0,001 \%}(18,64)\right) \\
\mathrm{M} 2 \text { vs. } \mathrm{M} 3=* * *\left(\hat{\mathrm{F}}_{59,33}>\mathrm{F}_{0,001 \%}(18,64)\right)\end{array}$} \\
\hline
\end{tabular}

\begin{tabular}{|c|c|c|c|}
\hline $\begin{array}{l}\text { Glucose } \\
(\mathrm{mg} / \mathrm{dL})\end{array}$ & $\begin{array}{c}\text { Adult females } \\
\text { NP }\end{array}$ & $\begin{array}{c}\text { Females at } 15 \text { days of } \\
\text { gestation } \\
\text { P1 }\end{array}$ & $\begin{array}{c}\text { Females at } 15 \text { days of } \\
\text { gestation } \\
\text { P2 }\end{array}$ \\
\hline$\overline{\mathrm{x}} \pm s_{\mathrm{x}}$ & $62.43 \pm 9.41$ & $51.88 \pm 6.00$ & $51.61 \pm 7.72$ \\
\hline $\mathrm{V} \%$ & 39.89 & 30.61 & 39.57 \\
\hline ANOVA & \multicolumn{3}{|c|}{$\begin{array}{l}\text { M1 vs. } M 2=\text { n.s. }\left(\hat{\mathrm{F}}_{0,89}<\mathrm{F}_{0,05 \%}(4,75)\right) \\
\text { M1 vs. } \mathrm{M} 3=\text { n.s. }\left(\hat{\mathrm{F}}_{0,79}<\mathrm{F}_{0,05 \%}(4,75)\right) \\
\text { M2 vs. } \mathrm{M} 3=\text { n.s. }\left(\hat{\mathrm{F}}_{0,0007}<\mathrm{F}_{0,05 \%}(4,75)\right)\end{array}$} \\
\hline
\end{tabular}

Table 2

CHANGES IN SERUM CHOLESTEROL LEVELS IN THE STUDIED DOES

Table 3

CHANGES IN SERUM TRIGLYCERIDE LEVELS IN STUDIED DOES

Table 4

CHANGES IN SERUM GLUCOSE LEVELS DURING PREGNANCY IN STUDIED DOES 


\begin{tabular}{|c|c|c|c|}
\hline $\begin{array}{c}\text { AST } \\
\text { (U/L) }\end{array}$ & $\begin{array}{c}\text { Adult females } \\
\text { NP }\end{array}$ & $\begin{array}{c}\text { Females at 15 } \\
\text { days of gestation } \\
\text { P1 }\end{array}$ & $\begin{array}{c}\text { Females at 15 } \\
\text { days of gestation } \\
\text { P2 }\end{array}$ \\
\hline$\overline{\mathbf{X}} \pm \mathrm{s}_{\mathbf{x}}$ & $42 \pm 5.93$ & $27.84 \pm 4.63$ & $77.87 \pm 9.75$ \\
\hline $\mathrm{V} \%$ & 37.39 & 44.03 & 33,13 \\
\hline & \multicolumn{3}{|c|}{ M1 vs. M2 $=$ n.s. $\left(\hat{\mathrm{F}}_{3,53}<\mathrm{F}_{0,05 \%}(4,75)\right)$} \\
ANOVA & \multicolumn{3}{|c|}{$\begin{array}{c}\text { M1 vs. M3 }=* *\left(\hat{\mathrm{F}}_{9,87}>\mathrm{F}_{0,01 \%}(9,33)\right) \\
\text { M2 vs. M3 }=* * *\left(\hat{\mathrm{F}}_{21.46}>\mathrm{F}_{0,001 \%}(18,64)\right)\end{array}$} \\
\hline
\end{tabular}

Table 5

RESULTSON AST STATUS IN STUDIED DOES

Table 6

RESULTS ON ALT STATUS IN STUDIED DOES

\begin{tabular}{|c|c|c|c|}
\hline $\begin{array}{l}\text { Calcium } \\
(\mathrm{mg} / \mathrm{dL})\end{array}$ & $\begin{array}{c}\text { Adult females } \\
\text { NP }\end{array}$ & $\begin{array}{c}\text { Females at } 15 \\
\text { days of gestation } \\
\text { Pl }\end{array}$ & $\begin{array}{c}\text { Females at } 15 \\
\text { days of gestation } \\
\text { P2 }\end{array}$ \\
\hline$\overline{\mathrm{x}} \pm \mathrm{s}_{\mathrm{x}}$ & $1.97 \pm 0.07$ & $1.92 \pm 0.08$ & $1.97 \pm 0.07$ \\
\hline $\mathrm{V} \%$ & 10.02 & 11.08 & 10.02 \\
\hline ANOVA & \multicolumn{3}{|c|}{$\begin{array}{l}\text { M1 vs. } M 2=\text { n.s. }\left(\hat{F}_{0,15}<F_{0,05 \%}(4,75)\right) \\
\text { M1 vs. } M 3=\text { n.s. }\left(\hat{F}_{1,21}<F_{0,05 \%}(4,75)\right) \\
\text { M2 vs. M3 }=\text { n.s. }\left(\hat{F}_{0,43}<F_{0,05 \%}(4,75)\right)\end{array}$} \\
\hline
\end{tabular}

Table 7

VARIATIONS IN CALCEMIA LEVELS IN STUDIED DOES

\begin{tabular}{|c|c|c|c|}
\hline $\begin{array}{l}\text { Phosphorus } \\
\text { ( } \mu \mathrm{g} / \mathrm{dL})\end{array}$ & $\begin{array}{c}\text { Adult females } \\
\text { NP }\end{array}$ & $\begin{array}{c}\text { Females at } 15 \text { days of } \\
\text { gestation } \\
\text { P1 }\end{array}$ & $\begin{array}{c}\text { Females at } 15 \\
\text { days of gestation } \\
\text { P2 }\end{array}$ \\
\hline$\overline{\mathrm{x}} \pm \mathrm{s}_{\mathrm{x}}$ & $7.59 \pm 0.16$ & $7.56 \pm 0.15$ & $3.74 \pm 0.57$ \\
\hline $\mathrm{V} \%$ & 5.69 & 5.42 & 40.89 \\
\hline ANOVA & & $\begin{array}{l}\text { s. }=\text { n.s. }\left(\hat{\mathrm{F}}_{0,01}<\mathrm{F}_{0,0}\right. \\
\mathrm{M} 3=* * *\left(\hat{\mathrm{F}}_{41,03}>\mathrm{F}_{0,00}\right. \\
\mathrm{M} 3=* * *\left(\hat{\mathrm{F}}_{40,67}>\mathrm{F}_{0,00}\right.\end{array}$ & $\begin{array}{l}(4,75)) \\
(18,64)) \\
(18,64))\end{array}$ \\
\hline
\end{tabular}

Table 8

VARIATIONSIN PHOSPHOREMIA LEVELS IN STUDIED DOES
(AST) and alanine aminotransferase (ALT). The two parameters are used as indicators of liver function, as markers of physiological conduct of pregnancy. The values determined on the three physiological stages (table 5 and 6) were similar with those reported by Wells et al. in 1999 [39].

ALT (alanine aminotransferase) or glutamate-pyruvate transaminase (GPT) is an enzyme that belongs to the transferases class and catalyzes the reversible transfer of amino group ( $\mathrm{NH} 2$ ) from an amino acid (alanine) and $\alpha$ ketoglutarate leading to the formation of pyruvic and glutamate acid. It is found mainly in the liver (at the liver cell level being especially in the cytosol) and kidneys, myocard, skeletal muscle and pancreas.

If the energy metabolism of cell liver is disturbed by infectious (e.g. viral hepatitis) or toxic agents, an increase in cell membrane permeability occurs, with the passing in serum of cytoplasmic components (cytolysis) [40].

ALT is the most frequently explored cytolysis indicator and in the opinion of most authors is the most suitable for detecting even minimal liver lesions [41]. ALT is more specific for hepatic disorders than aspartate aminotransferase (AST). Absolute ALT values do not correlate, however, directly with the severity of the liver injury and the prognosis, and because of this, serial determinations are the most useful [42].

In this study, ALT activity decreased to day 15 of pregnancy, when the organogenesis ended, remaining at low levels until the end of pregnancy.

Calcium and phosphorus, within mineral homeostasis, own a capital importance, as they are present in both cells and humors and perform multiple and complex roles, conditioning each other at all metabolic stages [43-45].

The amount of total calcium in the studied does did not record significant variations in the three physiological stages taken in study (table 7).

Knowing that calcium homeostasis in the body is achieved by rapid exchanges between plasma calcium and the one in the bone and cellular compartments, we can conclude that the values recorded by us reveals a balance between the needs of organism and the feed intake $[46,47]$.

Approximately $45 \%$ of the total amount of plasma calcium is related to albumin (and only a small amount of globulins) in non-ionised and non-diffused form, constituting a physiologically inactive form $[48,49]$.

Phosphoremia may exhibit very wide variations, its value being related to carbohydrate metabolism. A hyperglucidic feeding leads to a decrease in phosphoremia, while the use of glucides in reduced proportions makes phosphoremia grow [50]. Phosphorus values have decreased during the last pregnancy period, $3.74 \mu \mathrm{g} / \mathrm{dL}$ compared to Al-Eissa [27] who reported constant values in all three physiological stages of pregnancy (table 8).

\section{Conclusions}

Results obtained on total protein did not record significant variations between the three physiological stages taken in the study despite the fact that the body's protein needs increased continuously due to the permanent transfer of amino acids to fetuses. Amino acids are necessary both for the development of conception 
products, but also for the uterus, fetal annexes, hemoglobin, and plasma proteins. This is explained by the administration of a completely combined fodder, balanced according to the physiological female condition.

Maternal energy metabolism in the second half of pregnancy is diverted towards the consumption of lipid, fact demonstrated by the results, low levels of cholesterol and triglycerides have been expressed during this period.

By analyzing the results of carbohydrate metabolism, we note that there are no significant differences between the three physiological states of does. This is explained by the fact that in pregnancy due to essential metabolic changes, the females use for their own energy needs fats to save glucose, the essential energy substrate for fetuses.

\section{References}

1.BOISTEANU, P.C., LAZAR, R., The profil of the main blood celular compounds at rabbit, related to the organism physiological condition, Scientific Papers, vol. LI, 2008. p. 208

2.ANGELO, I.A., SRIVASTAVA, A., Milchwissenschaft, 34, 1979, p. 220. 3.ARCHETTI, I., TITTORELLI, C., CERIOLI, M., BRIVIA, R., GRILLI, G., LAVAZZA, A., 9th World Rabbit Congress, Verona, Italy, 2008, p 1147. 4.BOISTEANU, P.C., LAZAR, R., The 36th International Session of Scientific Communications, USAMV Bucuresti, 2007, p. 189.

5.MARIN, M., NICOLAE, C.G., DRAGOTOIU D., URDES, L. RADUCUTA I., DINITA G., Scientific Papers. Series D. Animal Science, vol. LVIII, 2015, p. 209.

6.BEAUDAIN, S., BARBET, P., BARGY, F., J. Fetal Diagnosis and Therapy, 18, no. 6., 2003, p.422.

7.MIZOGUCHI, Y., MATSUOKA, T., MIZUGUCHI, H., ENDOH, T., KAMATA, R., FUKUDA, K.T., ISHIKAWA, T., ASANO, Y., Lab. Anim., 44, 2010, p. 33.

8.BJ ELLIN, L., CARTER, A.M., Biol. Reprod., 16, 1977, p. 112.

9.COUREAUD, G., SCHAAL, B., COUDERT, P., RIDEAU, P., FORTUNLAMOTHE, L., HUDSON, R., ORGEUR, P., Reprod. Nutr. Dev., 40, 2000, p. 19.

10.MARIN, M., DRAGOTOIU, D., RADUCUTA, I., NICOLAE C.G., SGEM2014 - Conference Proceedings, 2, 2014, p. 595

11.BLASCO, A., ORTEGA, A.J., SANTACREU, A.M., CLIMENT, A., J. Anim. Sci., 83, no. 10, 2005, p. 2297.

12.MARIN, M., DRAGOTOIU, D., NICOLAE, C.G., DINITA G., AgroLife Scientific Journal, 4, no. 2, 2015, p. 48.

13.AMES, A., LI, Y.Y., HEHER, E.C., KIMBLE, C.R., J. Neuroscience, 12, 1992, p. 840.

14.MACRI, A.M., CATOI, C, DANCEA, Z., SEVASTRE, B., DROCHNER, W., BABA, A.I., Buletin USAMV-CN, 62, 2005, p. 166.

15.PASCUAL, J.J ., SAVIETTO, D., CERVERA, C., BASELGA, M., World Rabbit Science, 21, 2013, p.123.

16.MACRI, A.M., DANCEA, Z., MICLAUS, V., MORAR, M.V., SZAKACS, A., SCURTU, I., Buletinul Societatii Romane de Biologie Celulara SRBC, 37, 2009, p. 97.

17.MOCE, M.L., SANTACREU, M.A., CLIMENT, A., PERIRO, R., BLASCO, A., Biochem. J., 391, 2005, p. 581.

18.TETSUYA, M., YASUMOTO, M., KOTARO, S., TOSHIKAZU, I., HIROGASU, M., YOUZO, A., The J ournal of Toxicological Sciences, 31, no. 2, 2006, p. 169.

19.ABU EL-ELLA, A.A., EL-GOHARY, E.S., ABDEL-KHALEK, T.M.M., ABDEL, S.A.M., J. Sheep Goat Sci., 9, 2014, p. 43.

20.***Laboratory Corporation of America. Directory of Services and Interpretive Guide. ALT. www.labcorp.com 2015. Ref Type: Internet Communication.
21.***Laborator Synevo. Referinte specifice tehnologiei de lucru utilizate 2015. Ref Type: Catalog

22.LAZAR, R., BOISTEANU, P.C., LAZAR, M., Lucrari Stiintifice, seria Zootehnie, 51, nr. 13, 2008, p. 223

23.AHMADI, M., NICULA, M., DUMITRESCU, G., STEF, L., PET, I., PETCULESCU-CIOCHINA, L., DRONCA, D., Rev. Chim. (Bucharest), 69, no. 10, 2018, p. 2731

24.BEAUVILLE, M., RAYNAUD, P., J. Physiol., 56, 1964, p. 287.

25.BLOCK, W.D., HUBBARD, R.W., Arch. Biochem. Biophys., 96, 1962, p. 557.

26.MARIN, M., NICOLAE, C.G., TAPALOAGA, D., PETCU, C., TAPALOAGA, P.R., DINITA, G., Current Opinion in Biotechnology, 24, supplement 1, 2013, p. S51.

27.AL-EISSA, M.S., British Biotechnology J ournal, 1, no. 1, 2011, p. 10. 28.ALVARIÑO, J.M.R., 7th World Rabbit Congress, Valencia - Spain, World Rabbit Sci., 8, supplement No. 1 A, 2000, p. 13.

29.WAHAB, A., KHAN, H., AHMAD, S., QURESHI, M.S., MUHAMMAD, Y., KHAN, S., SADIQUE, U., SHAH, M.K., Pakistan J. Zool., 48, no. 3, 2016, p. 625.

30.LAZAR, R., MARCU, E., BOISTEANU, P.C., LAZAR, M., Lucrari Stiintifice, seria Medicina Veterinara, 50, 2007, p.168 .

31.ABINAYA, A., PASUPATHI, K., KARUNAKARAN, R., JOSEPH, C., SENTHIL, N.R., VAIRAMUTHU, S., International Journal of Chemical Studies, 6, no. 3, 2018, p. 991.

32.BOLET, G., BRUN, J.M., LECHEVESTRIER, S., LOPEZ, M., BOUCHER, S., Anim. Res., 53, 2004, p. 59.

33.MACOVEI, L.A., BIRSAN, M., TEODOR, V.I., CRISTOFOR, A.C., IOANID, N., REZUS, E., Rev. Chim. (Bucharest), 68, no. 4, 2017, p 1689.

34.MIRANDA, J.E., MARIN, A., MARRERO, L.I., GARCIA, Y., GARCIADIAZ, J.R., Cuban Journal of Agricultural Science, 52, no. 1, 2018, p. 35.KHAN, H., KUSAKABE, K.T., WAKITANI, S., HIYAMA, M., KISO, Y., J. Vet. Med. Sci., 73, 2011, p. 1177.

36.YASUMOTO, M., TETSUYA, M., HIROYASU, M., TAKAKO, E., RYO, K., KAZUYA, F., TSUTOMU, I., ASANO, Y., Laboratory animals, 44, 2010, p. 33.

37.LIXANDRU, D., MORARU, L., ALEXANDRU, P., STOIAN, I., ROa CA, A., GHITA, M., CARUNTU, C., CARUNTU, A., IONESCU-TIRGOVISTE, C., GUJA, C., Rev. Chim. (Bucharest), 67, no. 11, 2016, p. 2332. 38.TALVEKAR, B.A., PATIL, R.R., INGOLE, S.D., BHARUCHA, S.V., Indian J. of Animal sciences, 78, no. 3, 2008, p. 247.

39.WELLS, M.Y., DECOBECQ, C.P., DECOUVELAERE, D.M., JUSTICE, C., GUTTIN, P., Toxicol Pathol, 27, 1999, p. 370.

40.KHATUN, A., WANI, G.M., BHAT, J.I.A., CHOUDHURY, A.R., KHAN, M.Z., Asian J. Anim. Vet. Adv., 6, 2011, p. 175.

41.STEC, A., MOCHOL, J., Bull. Vet. Inst. Pulawy, 50, 2006, p. 199.

42.DUMITRU, G., TODIRASCU-CIORNEA, E., HRITCU, L., SANDU, I.G., Rev. Chim. (Bucharest), 69, no. 5, 2018, p. 1194.

43.MEENAKSHI, V., MALIK, R.K., SINGH, P., DALAL, S.S., Haryana Vet., 50, 2011, p. 77.

44.PATRASCU, S., UNGUREANU, B., NICOLAU, C., COPAESCU, C., SAFTOIU, A., SURLIN, V., ANDRONIC, D., ROBU, S., Rev. Chim. (Bucharest), 68, no.7, 2017, p.944.

45.DELEANU, B., SCURTU, M., AHMADI, M., TULCAN C., PREJ BEANU, R., DRONCA, D., Rev. Chim. (Bucharest), 66, no. 9, 2015, p. 455. 46.TABATABAEl, S., Comp. Clin. Pathol., 21, 2011, p. 1305. 47.VERMESAN, H., PUP, M., AHMADI, M., OLARIU, L., VERMESAN, D., PREJBEANU, R., Rev. Chim. (Bucure-oti), 59, no. 8, 2018, p. 2731. 48.BESANÇON, P., LEBAS, F., Ann. Zootech., 18, 1969, p. 437. 49.CAMPBELL, T.W., Veterinary Hematology and Clinical Chemistry, 1st edition, Lippincott Williams and Wilkins, 2004, p. 211. 50.HASSABO, A., 2008. Pak. J. Nutr., 7, 2008, p. 811.

$\overline{\text { Manuscript received:12.11.2018 }}$ 